\title{
Lethal congenital contracture syndrome (LCCS), a fetal anterior horn cell disease, is not linked to the SMA 5q locus
}

Katri Vuopala, Päivi Mäkelä-Bengs, Anu Suomalainen, Riitta Herva, Jaakko Leisti, Leena Peltonen

\begin{abstract}
The lethal congenital contracture syndrome (LCCS) is an autosomal recessive syndrome (McKusick 253310) leading to perinatal death owing to early onset degeneration of the anterior horn motor neurones of the spinal cord. The neuropathological findings in the LCCS closely resemble those of spinal muscular atrophy (SMA). Since all the three types of SMA have been localised to the same gene locus on the long arm of chromosome 5, we analysed samples from seven families with 10 LCCS fetuses with the microsatellite markers assigned to the SMA 5q region. Linkage analyses between the SMA linked DNA markers and the disease allele in the LCCS families excluded the critical chromosomal region around the SMA locus as the critical chromosomal region for the LCCS locus.
\end{abstract}

( $(\mathcal{H}$ Med Genet 1995;32:36-38)

The lethal congenital contracture syndrome (LCCS) is an autosomal recessive syndrome (McKusick 253310), so far reported mostly in Finland. ${ }^{1}$ It leads to perinatal death and the fetuses typically have hypoplastic lungs, marked skeletal muscle hypoplasia, and contractures of the extremities. ${ }^{2}$ The pathological mechanism of LCCS, the early onset degeneration of the anterior horn motor neurones of the spinal cord, has been well documented. ${ }^{3}$

The neuropathological findings in LCCS closely resemble those of spinal muscular atrophy (SMA). Three different forms of SMA can be distinguished by the age of onset and the course of the disease. ${ }^{4}$ Since all three types share a gene locus at $5 \mathrm{q} 13.3$, between the polymorphic DNA markers D5S435 and D5S39, ${ }^{5-8}$ the question arises whether LCCS might represent an extreme form of SMA. To study this hypothesis, we performed linkage analysis using samples from seven Finnish families with 10 LCCS fetuses and the markers closely linked to or flanking the SMA locus on $5 q$.

\section{Methods and results}

Fig 1 shows the LCCS pedigrees used in this study. Peripheral blood samples were stored at $-20^{\circ} \mathrm{C}$ and were available from 14 parents and seven healthy children. Total DNA was isolated according to standard procedures. ${ }^{9}$
The polymorphic microsatellite markers (D5S407, D5S435, D5S351， D5S39, D5S424) ${ }^{81011}$ assigned to the SMA 5q region were amplified using polymerase chain reaction (PCR). PCR was performed in a microtitre well format as described previously. ${ }^{12}$ All the primer sequences of the markers originated from the amplifiable marker collection of Généthon (The Généthon Microsatellite Map Catalogue 1993) or that of the Nordic Human Genome Organisation.

We carried out data simulation for the LCCS family material in the linkage analyses assuming a single marker locus and double heterozygosity
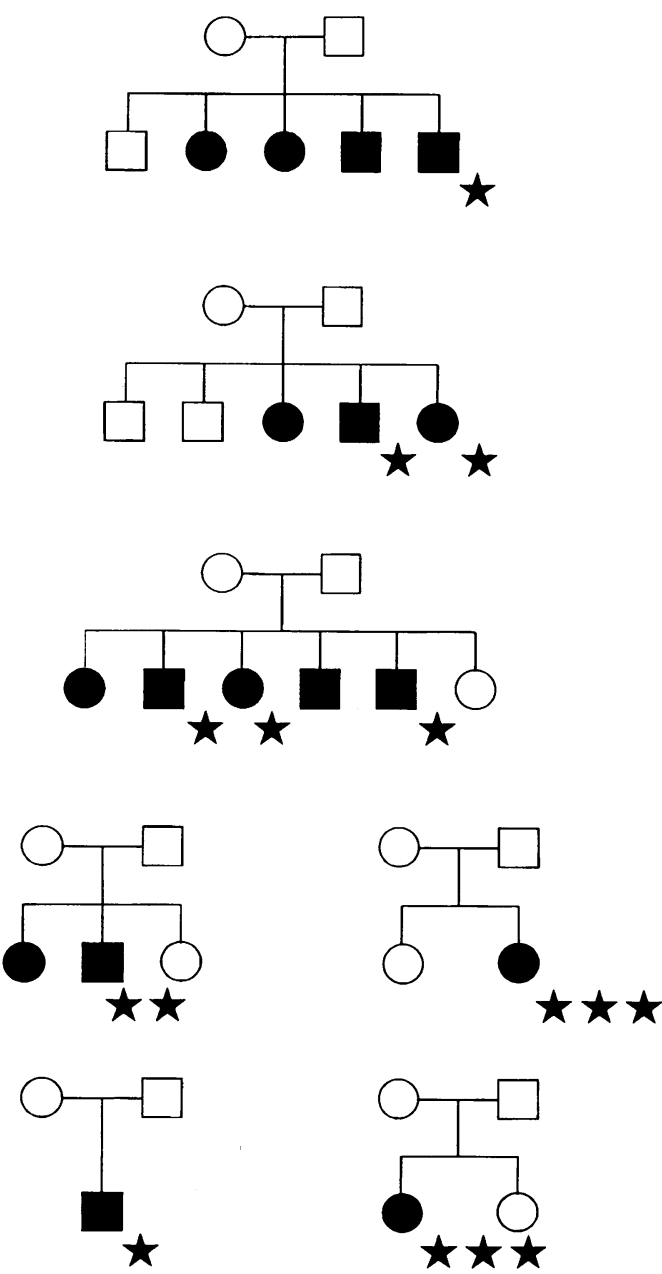

Figure 1 The pedigrees of the families studied. Filled symbols denote affected members, open symbols denote unaffected spouses. One star indicates subjects from whom fibroblasts were available for DNA isolation, two stars those from whom placenta was collected, and three stars those from whom placenta was collected, and three stars
those from whom liver biopsy was available for DNA those from whom liver biopsy was available for DNA
isolation. Peripheral blood samples were available from all unaffected family members. 


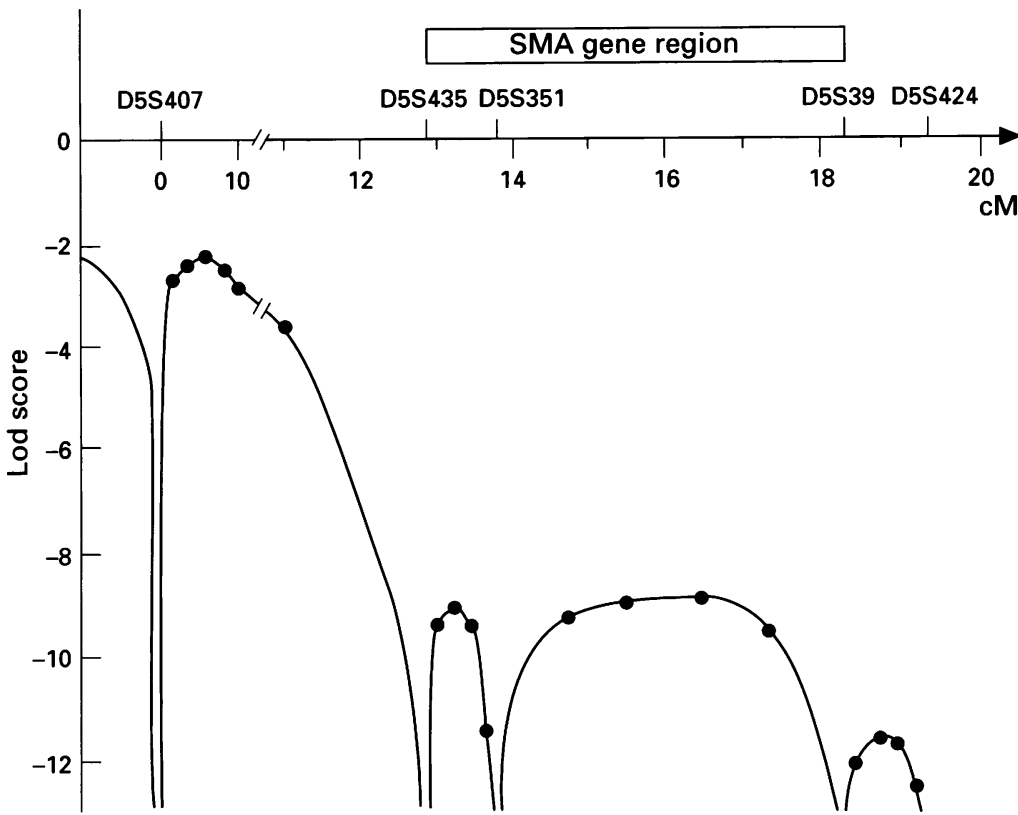

Figure 2 The result of multipoint linkage analyses of LCCS and SMA. The critical chromosomal region was considered excluded with lod score values below -1.5 of flanking or closely linked markers. The markers are shown above the horizontal axis and genetic distances between markers are expressed in centiMorgans (cM).

Pairwise linkage data between LCCS and markers flanking the SMA locus

\begin{tabular}{llllll}
\hline Marker & \multicolumn{6}{l}{ Recombination fraction } \\
\cline { 2 - 6 } & 0.00 & 0.01 & 0.05 & 0.07 & 0.1 \\
\hline D5S407 & $-\infty$ & -1.7 & -0.51 & -0.30 & -0.12 \\
D5S435 & $-\infty$ & -2.9 & -1.5 & -1.2 & -0.93 \\
D5S351 & $-\infty$ & -6.1 & -2.8 & -2.2 & -1.6 \\
D5S39 & $-\infty$ & -4.3 & -2.2 & -1.8 & -1.4 \\
D5S424 & $-\propto$ & -5.0 & -2.4 & -1.9 & -1.4 \\
\hline
\end{tabular}

in the parents to analyse the informativeness of our family material. The MSIM option of the SLINK computer program ${ }^{13}$ was used with 2000 replicates (one replicate equals one round of generating marker genotype for each subject) to obtain the elod values (expected logarithm of odds score). This simulation analysis showed an average elod of 1.4 at the recombination fraction $(\theta) 0.07$, SD 0.5 . The elod values remained over 1.0 at $\theta 0.13$ with $85 \%$ of replicates.

Linkage analyses between the disease locus of LCCS and the polymorphic marker loci were carried by using the MLINK and LINKMAP options of the LINKAGE package computer program (version $5 \cdot 1$ ). ${ }^{14}$ The frequency applied for the disease allele was $0.016^{1}$ with complete penetrance. Locus homogeneity was assumed owing to the enrichment of the diseases in the genetically isolated Finnish population and the homogeneity of the clinical presentation.

The marker D5S39 is reported to be the closest marker to the SMA locus with D5S39 and D5S435 being distal and proximal flanking markers, respectively. ${ }^{811}$ The results of the two point analyses are summarised in the table. No evidence of linkage between any of the markers and the LCCS locus was found, and only negative lod scores were obtained at the recombination fractions $\leq 0 \cdot 1$. Also the multipoint linkage analyses with the markers resulted in negative lod scores excluding a continuous area $13.7 \mathrm{cM}$ proximal to D5S351, the closest marker to the SMA locus, and $11 \mathrm{cM}$ distal to it (fig 2). These data show that the LCCS locus is not allelic with SMA.

\section{Discussion}

Diseases affecting anterior horn cells are a heterogeneous group of neurodegenerative disorders which may become manifest at any time of life. ${ }^{15}$ The most common of these disorders is spinal muscular atrophy. The assignment of the SMA loci to chromosome $5 \mathrm{q}$ has made prenatal diagnosis possible for SMA families. However, it has led to confusion in the families with so-called variants of SMA, that is, diseases with anterior horn cell involvement and a phenotype atypical of SMA. ${ }^{16}$ The group of "variants" of infantile SMA, or more precisely anterior horn cell disease (AHD), includes two subgroups that resemble LCCS: cases with AHD and multiple congenital fractures and cases with AHD and early respiratory insufficiency. ${ }^{17}$

It has been suggested that the SMA variants differ genetically from SMA 5q. ${ }^{4}$ The reported pedigrees with AHD and arthrogryposis suggest autosomal recessive transmission, ${ }^{18}$ but $\mathrm{X}$ linked inheritance cannot be excluded. ${ }^{1920} \mathrm{~A}$ linkage study in a consanguineous family with two affected males out of five sibs was performed resulting in exclusion of 5q. ${ }^{21}$ Our results excluding the SMA 5q locus as the LCCS gene locus show that LCCS does not represent a subtype of SMA, but is a genetically distinct syndrome.

At present, the prenatal diagnosis of LCCS is based on sonographic findings of fetal akinesia and hydrops. ${ }^{22}$ The localisation of the LCCS gene would make specific prenatal diagnosis available for LCCS families. In addition to the clinical advantage, the further characterisation of LCCS would provide data on the molecular pathomechanism of motor neurone disease.

We would like to thank Pekka Laurila and Riitta Salonen for identifying the LCCS fetuses and sending us the tissue samples. Jaakko Ignatius is thanked for valuable comments on current knowledge of SMA. This study was supported by Emil Aaltonen Foundation, Finland.

1 Vuopala K, Herva R. Lethal congenital contracture syndrome: further delineation with genetic aspects. $\mathcal{F} \mathrm{Med}$ Genet 1994;31:521-7.

2 Herva R, Leisti J, Kirkinen P, Seppänen U. A lethal autosomal recessive syndrome of multiple congenital contractures. Am 7 Med Genet 1985;20:431-9.

3 Herva R, Conradi NG, Kalimo H, Leisti J, Sourander P. A syndrome of multiple congenital contractures: neuropathological analysis on five cases. Am 7 Med Genet 1988 . 29:67-76.

4 Munsat TL. Workshop report. International SMA collaboration. Neuromusc Disord 1991;1:81.

5 Brzustowicz LM, Lehner T, Castilla LH, et al. Genetic mapping of chronic childhood-onset spinal muscular atrophy to chromosome 5q11.2-13.3. Nature 1990;344:5401 .

6 Melki J, Abdelhak S, Sheth P, et al. Gene for chronic proximal muscular atrophies maps to chromosome 5q. Nature 1990;344:767-8.

7 Gilliam TC, Brzustowicz LM, Castilla LH, et al. Genetic homogeneity between acute and chronic forms of spinal muscular atrophy. Nature 1990;345:823-5.

8 Burghes AHM, Ingraham SE, Kote-Jarai Z, et al. Linkage mapping of the spinal muscular atrophy gene. Hum Genet 1994;93:305-12.

9 Davies LG, Dibner MD, Battey JF. In: Leder P, ed. Basic methods in molecular biology. New York: Elsevier Science Publishing, 1986:47-50.

10 Soares VM, Brzustowicz LM, Kleyn PW, et al. Refinement of the spinal muscular atrophy locus to the interval between 
D5S435 and MAP1B. Genomics 1993;15:365-71.

11 Wirth B, Voosen B, Röhrig D, et al. Fine mapping and narrowing of the genetic interval of the spinal muscular atrophy region by linkage studies. Genomics 1993;15: 113-18.

12 Aaltonen J, Komulainen J, Vikman A, et al. Autoimmune polyglandular disease type 1 . Exclusion map using amplifiable multiallelic markers in a microtiter well format. Eur f Hum Genet 1993;1:164-71.

13 Ott J. Computer-simulation methods in human linkage analysis. Proc Natl Acad Sci USA 1989;86:4175-8.

14 Lathrop GM, Lalouel JM, Julier C, Ott J. Strategies for multilocus linkage in humans. Proc Natl Acad Sci USA multilocus linkage

15 Swash M, Schwartz MS. Neuromuscular diseases. 2nd ed. London: Springer, 1988:85-122.

16 Dubowit V. Edity muscular atrophies of childhood. Neurmusc Disord 1991; muscular a

17 Ignatius J. Meeting report. International SMA Consortium meeting. Neuromusc Disord 1992;2:424-6.

18 Borochowitz Z, Glick B, Blazer S. Infantile spinal muscular atrophy (SMA) and multiple congenital bone fractures in sibs: a lethal new syndrome. $\mathcal{f}$ Med Genet 1991;28: 345-348.

19 Greenberg F, Fenolio KR, Heitmancik JF, et al. X-linked infantile spinal muscular atrophy. Am $\mathcal{f}$ Dis Child 1988 , 142:217-19.

20 Baumbach L, Bhaskar A, Hoffman E, Edwards J, Hejtmanick JF, Best B. X-linked infantile lethal anterior horm cell A diseases provides evidence for genetic heterogeneity within the proximal spinal muscular atrophies. Am f Hum Genet
Suppl 1993;53:399A.

21 Lunt PW, Mathew C, Clark S, et al. Can prenatal diagnosis be offered in neonatal lethal spinal muscular atrophy (SMA) with arthrogryposis and fractures? $f$ Med Genet (SMA) with arthro

22 Kirkinen P, Herva R, Leisti J. Early prenatal diagnosis of lethal syndrome of multiple congenital contractures. Prenat Diagn 1987;7:189-96. 